\title{
Appraisal of literature on customer experience in tourism sector: review and framework
}

\begin{abstract}
A substantial body of literature has been built up in experience marketing. In spite of that there is no cohesive framework that has systematically examined antecedents, formation and implications of customer experience, or has classified different aspects of customer experiences. The purpose of this article is to derive an integrative review of published articles on consumer experience and its related topics. The study synthesizes the research on customer experience through two different but interrelated streams: (1) experience as a product attribute or a complete product and (2) consumer experience created due to customer interaction with the physical environment or people. This article develops a framework that corroborates literature related to

(1) definitional aspects of customer experience, (2) formation of customer experience,

(3) asserting consumer psychology in engaging in the creation of experience and its consumption and (4) the effects of customer experience. We first review available prior research and present the salient features of these articles and their findings. The research gaps are then identified and a set of propositions provided, followed by directions for future research. This article also identifies some methodological issues that are relevant in the context of individual level effect on customer experience.
\end{abstract}

Keywords: customer experience; experience marketing; review and framework; experience consumption

\section{Introduction}

The experiential consumption of products and services has of late attracted the attention of both academics and practitioners in developing marketing strategies. A plethora of articles related to the marketing of experience products and services for consumers in general and travellers in particular have been published in the last three decades in economics, market-ing, hospitality and psychology journals (Adhikari, 2014; Agapito, Mendes, \& Valle, 2013; Andersson, 2007; Brakus, Schmitt, \& Zarantonello, 2009; Brakus, Schmitt, \& Zhang, 2008; Chattopadhyay \& Laborie, 2005; Holbrook \& Hirschman, 1982; Huffman \& Houston, 1993; Schmitt, 2003, 1999; Shaw \& Ivens, 2002; Tung \& Ritchie, 2011). Also, both the March 2009 issue of Journal of Retailing (Grewal, Levy, \& Kumar, 2009; Puccinelli et al., 2009; Verhoef et al., 2009) and several issues of Annals of Tourism Research (Richards, 2011; Sharpley \& Jepson, 2011; Tung \& Ritchie, 2011) have devoted consider-able space to a discussion of the creation and management of travellers' experience, taking into consideration both the strategic- and the implementation-level perspectives. 
Studies by Binkhorst and Den Dekker (2009), Grewal et al. (2009) and Pine and Gilmore (1998, 1999) made considerable attempts to present experience as an independent product identity. They looked at experiential consumption from the context of both retail shopping and the physical tourism environment that a retailer or a hospitality service pro-vider presents to the customer, or from which the travellers derives pleasure. Their studies primarily concentrated on how the customer experience is created and how retailers lever-age it for the purpose of maximizing sales. In a related but different direction, researchers such as Verhoeff et al. (2009), Cutler and Carmichael (2010), Arnold, Reynolds, Ponder, and Lueg (2005), Holt (1995), Arnold and Price (1993) and Holbrook and Hirschman (1982) have explored experiential consumption through the emotions and feelings related to fantasy and fun. These studies posit that when travellers are involved with the product and experience a certain degree of interaction with it, it has a positive effect on the customer. As a result, travellers develop a positive purchase intention. Holbrook and Hirschman, in a seminal paper from 1982, indicated that consumers may also undertake experiential con-sumption for the aesthetics involved and the subjective benefits that they may derive from its consumption. This type of mentality has been labelled as "play mentality".

Recent reviews of the experiential consumption literature have not only summarized the role of macro factors like growth rate of the industry, inflation rate and discount rate that shape customer experience and behaviour in retail and tourism sectors (Chang, Stansbie,

\& Rood, 2014; Chen, 2007; Fluker \& Turner, 2000; Grewal et al., 2009; Puccinelli et al., 2009), but also presented the philosophical underpinning of the definition of consumer experience, specifically in the context of the hospitality and tourism industry (Feng \& Page, 2000; Walls, Okumus, Wang, \& Kwun, 2011). In spite of such a large volume of lit-erature available on the marketing of consumers' experiences that address both its theoreti-cal importance and managerial implications, there is no cohesive framework that has systematically examined its antecedents, formation and implications, or has classified different aspects of travellers' experiences in tourism literature. The purpose of this article is to derive an integrative review of published articles on consumer experience and its related topics in tourism literature, taking its antecedents from diverse body of literature.

Earlier researchers have considered multiple perspectives in examining different components of customer's experience in sociology (Cohen, 1979; Holbrook, 2006; Jafari, Pizam, \& Przeclawski, 1990), anthropology (Wang, 1999), stages of formation (Aho, 2001), marketing (Grewal et al., 2009; Kim \& Ritchie, 2014; Kim, 2012a; Schmitt, 1999) and repeat travel behaviour (Heimtun \& Abelsen, 2012; Ryan, 2000). Recent reviews done on tourism experience (Wang, 1999) also examined theoretical connection of development, creation and consumption of tourism experience; however, all these literature talk about customer experience in retail context or in tourism context. There was no demarcation of experiential consumption as product and experience creation in the value delivery process coordinating and synthesizing both genre of literature under single umbrella.

In an attempt to synthesize the research on travellers' experience, we consider literature in marketing as well as tourism industry. The primary reason for including literature in marketing is that trends of hospitality and tourism services in last two decades largely rely on marketing theory (Bramwell \& Rowding, 1994; Heath \& Wall, 1991; Smith, 1994). Research has shown that there is considerable influence of marketing theory and practice in hospitality and tourism sector, and hence, this article includes literature on experience product from both perspectives. In this context we identify two different but interrelated streams of research. The first stream deals with experience as a product attribute or a com-plete product (Gilmore \& Pine, 2002a; Haven-Tang \& Jones, 2010; Holbrook 
\& Hirschman, 1982; Parasuraman, Zeithmal, \& Berry, 1985; Pine \& Gilmore, 1998; Verhoef et al., 2009). This stream of literature considers the experience product as a stimu-lus that may or may not deliver tangible benefits leading to consumption utility, but that will act as a catalyst in performing hedonic functions. The second stream of research deals with consumer experience created due to customer interaction with the physical environment or people (Gentile, Spiller, \& Noci, 2007; Kastenholz, Davis, \& Paul, 1999; Meyer \& Schwa-ger, 2007; Rose, Clark, Samouel, \& Hair, 2012; Rose, Hair, \& Clark, 2010). This body of literature considers experience as a differentiator in delivering products and services. These two streams of literature are further related by way of consumption of experience. Con-sumption of experience could be (1) sensory or (2) participative. Sensory experience requires travellers to use their sensory organs for consumption, for example, during the con-sumption of a 3-D movie, a music concert or a similar event. On the other hand, participa-tive consumption engages travellers in the process of creation and consumption. In these cases, the services are experienced by the individual as they engage with them. These ser-vices may provide either pure experience, such as experiences in a theme park, or bundled or mixed experiences where the experience component is bundled with the service, such as dinner in a restaurant where the food is made according to the suggestion of the tourists.

We develop a framework that corroborates the findings from these two streams of literature. Specifically, the current understanding of experiential consumption is developed by a review of literature related to (1) definitional aspects of travellers' experience, (2) for-mation of travellers' experience along with its antecedents and key drivers, (3) asserting travellers' psychology in engaging in the creation of experience and its consumption and

(4) the effects of travellers' experience on product evaluation and purchase decision. For each of these four areas of experience research we first review available prior research in all related fields, and present the salient features of these articles and their findings. We also identify some methodological issues that are relevant in the context of customer experi-ence when these experiences are created and consumed at an individual level.

\section{Methods adopted in literature review}

In this study, a systematic review of the extant literature was carried out. The review ques-tion was identified as, "What is the domain and nature of customer experience in the business-toconsumer sector?" A research team comprising the both authors and one research associate gathered literature on (1) customer experience, (2) experience economy, (3) travellers' experience, (4) tourists' behaviour, (5) consumption experience and (6) experience construction. Research papers were extracted from online databases, including EBSCO, JSTOR and ABI ProQuest. We considered 62 peer-reviewed journals and edited books covering the scope of research related to the above area in selecting articles. Out of these, 22 were marketing journals, 20 were hospitality and tourism journals and edited books, 6 were consumer behaviour and consumer psychology journals, and 14 were other journals and books primarily related to business and management. First, we went through an article title and its abstract to explore the theme of article and to analyse whether our research objective was within its scope. Next, a content analysis was carried out manu-ally through which we selected 198 research articles to carry out the review. This method helped to provide a bird's eye view of the nature and extent of existing research in the area of customer experience, the methodology used in these studies and the findings of the research and their contribution. We then developed a form containing the salient constructs and sub-constructs covered in the framework of the article. Of the total number of Research articles reviewed in this paper dated from 1970 to 2014 that deal with customer experience. 
The sectors covered in these studies include travel and tourism, retail, entertainment and online purchase.

The conceptual framework

The concept of travel experience is driven by the creation and consumption of tourism and related products that not only provide experiences for the traveller but also create sensory feelings when travellers directly or indirectly interact with the organization, product and purchase environment on different occasions (Adhikari \& Rao, 2013; Daugstad, 2008; McGinnis, Gentry, \& Gao, 2012; Patrício, Fisk, Falcão e Cunha, \& Constantine, 2011; Meyer \& Schwager, 2007). The framework provided in Figure 1 provides the sequential flow of this review article. In the first block of the framework customer experience is divided into two categories: (1) experience as a product and (2) experience as a sensory interaction phenomenon. The significant area of research in this context deals with pure experience products such as rides in a theme park, cruise travel during vacations, and so on (Connel \& Meyer, 2004; Ellis \& Rossman, 2008; Finn, 2005; Kim, 2012b; Patrício et al., 2011; Zomerdijk \& Voss, 2010), and mixed experience products where experience attributes are combined with tangible products or services (Adhikari, Basu, \& Raj, 2013; Gilmore \& Pine, 2002b; Kwortnik \& Thompson, 2009). There is further evidence in the literature regarding experience as a sensory interaction in (1) the online environment (Klaus, 2013; Wen, 2013; Novak, Hoffman, \& Yong, 2000), (2) the store environment (Baker, Parasuraman, Grewal, \& Voss, 2002; Rose

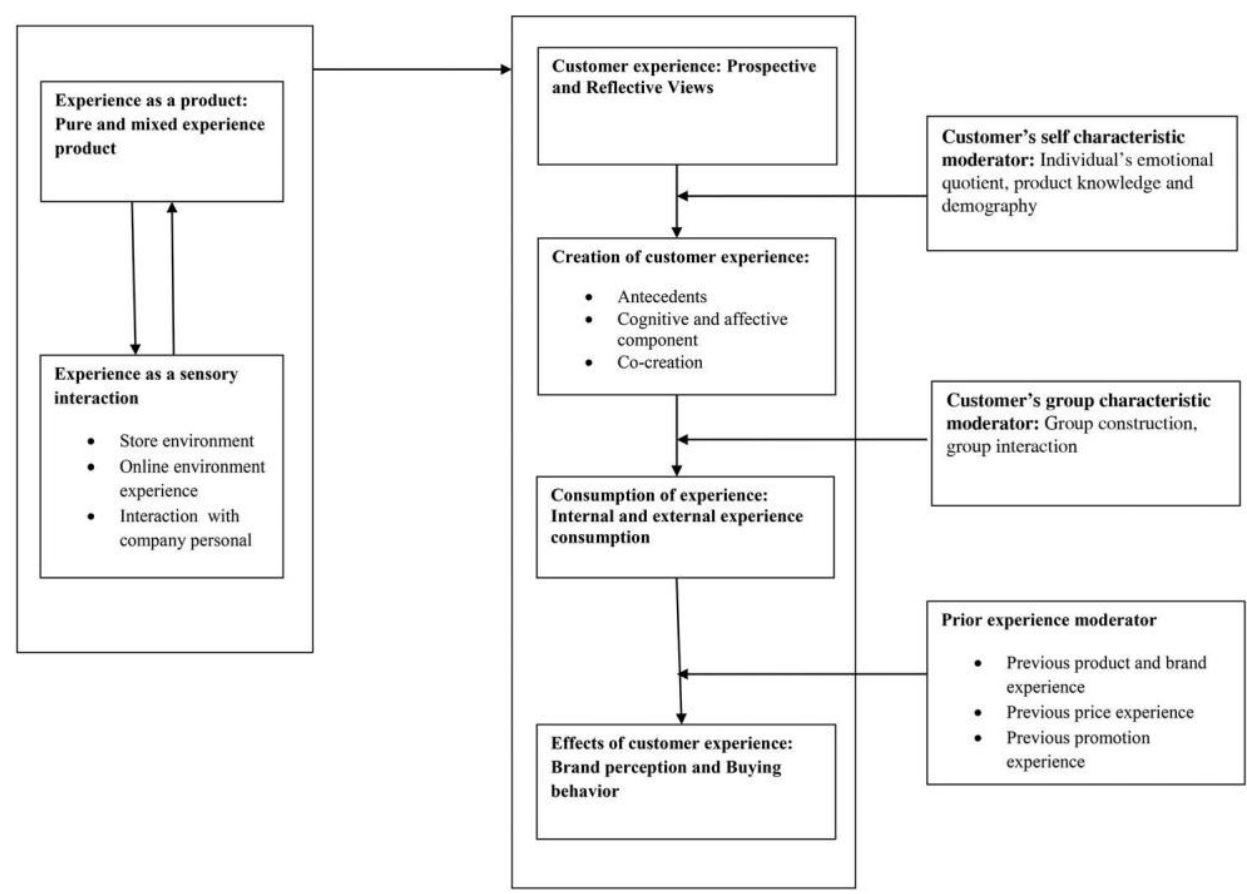

Figure 1. Framework of literature on customers' experience. 
et al., 2010; Kaltcheva \& Weitz, 2006) and (3) dealings with company personnel (Berry, Carbone, \& Haeckel, 2002).

The main part of the framework is divided into four areas of research. The first area synthesizes two types of definition of customer experience: prospective and reflective. Researchers who considered customer experience from the prospective view looked at customer experience as the customer's expectation of a sensory engagement with an experience product or experiential interaction they are about to have (Holbrook \& Hirschman, 1982; Oh, Fiore, \& Jeoung, 2007; Wilson \& Richards, 2008). On the other hand, researchers defining customer experience from the reflective perspective dealt with the customer's experience during or after the consumption of an experience product or sensory interaction (Gretzel \& Fesenmaier, 2003; Lewis \& Chambers, 2000; Schmitt, 1999). The second area of research synthesizes the formation of customer experience. The key research issues dis-cussed here are the antecedents of customer experience, the cognitive and affective com-ponents of customer experience and the co-creation of customer experience. The third area of research represents consumption of customer experience. Researchers have broadly described consumption of customer experience from two perspectives: internal experience consumption and external experience consumption. The fourth aspect of customer experi-ence research focuses on the effects of customer experience on their brand perception, buying behaviour (including repeat purchase behaviour) and volume of consumption. The framework also considers three moderators: (1) customer's self-characteristic moderator, (2) customer's group characteristic moderator and (3) prior experience moderator.

Experience as product: pure and mixed experience products

While a significant amount of literature deals with customer experience, there is a scarcity of literature that considers experience as an independent product (e.g. Haven-Tang, \& Jones, 2010; Parasuraman et al., 1985; Verhoef et al., 2009). Researchers such as Gilmore and Pine (2002b), Holbrook and Hirschman (1982) and Pine and Gilmore (1998) introduced the concept of consumption of experience attributes coupled with a product or service. In their seminal paper of 1982, Holbrook and Hirschman explained that, apart from deriving utilitarian benefits from the objective features of a product, a traveller may also derive hedonic/symbolic benefits by consuming the experiential attributes of the product. Also, there are products/services, such as watching a movie or a play, or enjoying skiing in the Alps, from which a traveller may derive a higher degree of hedonic benefit than utilitarian benefit. These symbolic benefits are derived from the active participation of the multisensory organs when an experiential product is being consumed.

Experience products can be of two types: pure experience product and mixed experience product. Pure experience products are those that engage travellers in the process of creation and/or consumption of experience. In these cases, the experiences are consumed by the individual as a complete product. Examples of such pure experience products are enjoying a ride in a theme park or visiting artefacts in a museum. Mixed experience products, on the other hand, are those where the experience components are bundled with tan-gible or intangible products, such as having dinner in a restaurant or watching a movie in a multiplex (Adhikari et al., 2013; Jennings \& Nickerson, 2006; Michelli, 2007; Wong, 2013). In the context of a restaurant, this experience is associated with service components such as the manner in which the food is served, the amount of time taken to serve it, the price charged and so on. The same restaurant can, however, also stage an experience in terms of the internal and external ambience, a specialty food menu, live music and other aspects that cater to special traveller needs (Adhikari et al., 2013). 
According to Kastenholz, Carneiro, Peixeira Marques, and Lima (2012) and Hopkinson Gillian and Pujari (1999), hedonic consumption takes place in a high-involvement situation, that is, an event that engages an individual completely. In the case of traditional commodities, products or services, there is very limited interaction of experience with the traveller's senses in the consumption process. The traditional buying decision models differ from experiential models in four distinct ways: mental constructs, product classes, product usage and individual difference (Holbrook \& Hirschman, 1982; Kastenholz \& Lima, 2011). In several buying situations, where the percentage of the experiential memorabilia is high in the product, the emotional desire to experience such memorabilia generates an exclusive utility for it (Arora, 2012). It creates different kinds of emotive arousal within the traveller, as a result of which they tend to buy an experience as a complete product and do not mind paying for it (Heimtun \& Abelsen, 2012; Zakrrison \& Zillinger, 2012).

\section{Experience as sensory interaction}

Many researchers have investigated customer experience through sensory interaction with the purchase environment and people (Gentile et al., 2007; Kastenholz et al., 1999; Meyer

\& Schwager, 2007; Rose et al., 2010, 2012). Studies related to customer experience show that customer interactions with the physical purchase environment, the online environment and store personnel create opportunities for positive customer experience.

\section{Customer experience in interaction with store environment}

Studies suggest that customer experience may originate from interactions between a custo-mer and a brand/product or company within stores (Baker et al., 2002; Kaltcheva \& Weitz, 2006; Meyer \& Schwager, 2007; Wakefield \& Baker, 1998). These researchers have focused on retail atmosphere, variety of product, assortment of brands and other elements in the marketing mix (Adhikari, 2014; Huffman \& Kahn, 1998). However, the literature in this area has largely concentrated on the aspect of environmental experience, which is under the control of the seller, and to what extent these elements affect consumers' purchase inten-tion and other behaviours (Janakiraman, Meyer, \& Morales, 2006; Lane, 2009). The effects of sensual stimulators such as scent, music and colour on travellers' buying behaviour in a retail context have also been studied (Naylor, Kleiser, Baker, \& Yorkston, 2008). These researchers have found that positive in-store environmental experiences create a positive effect on travellers' buying behaviour and subsequent purchase and store loyalty.

\section{Customer experience in interaction with online environment}

Customer experiences are also formed by interacting with an organization in an online environment. Studies by Lewis and Chambers (2000) focus on customer experience in online shopping when they get instant access to the Internet. The authors discuss several key aspects that could increase customers' positive experiences in relation to soft media. Studies related to customer experiences in their interaction in an online environment have largely dealt with website quality and constructs (Kaynama \& Black, 2000; Loiacono, Watson, \& Goodhue, 2002; Markwell, 2001), online customer behaviour in searching and purchasing (Lee \& Lin, 2005) and online service experience (Khalifa \& Liu, 2003; Middle-ton, 2011). A review of extant literature dealing with online customer experience was carried out by Rose et al. (2010). Their study synthesized literature that compared online and offline customer experiences, antecedents (Grant, Clarke, \& Kyriazis, 2007; Morgan, 
2010; Zeng \& Reinartz, 2003) and consequences (Khalifa \& Liu, 2007) of online customer experience. These researchers found that customer experience is a psychological state and has a direct relation with customer satisfaction in the online purchase environment.

\section{Customer experience in interaction with company personnel}

Customer experience of interacting with company personnel can have a positive impact on buying behaviour. For example, if a car is repaired and the vehicle delivered to the custo-mer, the customer is not engaged in the process of creation and consumption of the service. However, the same repair can be turned into a personal service, with the customer being present during the process of repairing the vehicle and directing the mechanic to do things in a certain way. The outcome of this experience and the reaction of the individual customers to this engagement may be varied (Morgan, Elbe, \& de Esteban Curiel, 2009). Customer experience created by interaction could involve direct as well as indirect dealings with the company or its product. Customers engage with a company at different levels, namely prepurchase, purchase and post-purchase activities, and these are generally directly related to a memorable event. Experience generated through indirect interaction is primarily related to a customer's recapitulation about the company or brand, word-of-mouth rec-ommendation and so on (Berry et al., 2002; Meyer \& Schwager, 2007).

$\mathrm{Wu}$ (2007) found that customer encounters with employees and the level of service they receive have a positive influence on both identity attractiveness and customer experience. Their study also found both consumer-company identification and customer satisfaction have a significant positive influence on customer loyalty.

Though the existing literature largely deals with customer experience of interaction with the online and offline environments and company personnel, literature also exists that deals with customer experience of interacting with other customers (Baron, Harris, \& Davies, 1996; Mossberg, 2007). Researchers have found that customer experience can be created by organizing interactions between customers both directly and indirectly; this can affect their decision-making and develop a positive customer attitude (Baker, 1987; Bitner, 1992; Neuhofer, Buhalis, \& Ladkin, 2012; Woodside \& Sims, 1976), as well as negative attitudes such as anxiety. Wu (2007) empirically studied the positive and negative effects of customer-to-customer interaction.

\section{Definition of customer experience: prospective and reflective views}

Gilmore and Pine (2002a), Joy and Sherry (2003) and Pine and Gilmore (1998) define experience as a bundle of sensory memorabilia. These, the authors argue, engage the five senses of the customer and succeed in delivering a sensory feeling. When customers buy an experience, they pay in order to associate themselves with a series of memorable events that an experience provider stages (Joy \& Sherry, 2003; O'Sullivan \& Spangler, 1998). Also, a company succeeds in delivering an experience when it stages events that engage customers in a memorable way for a prolonged duration (Pine \& Gilmore, 1999).

Taking a philosophical route to traveller experience, Walls et al. (2011) found that clutter and confusion exist regarding the definition of traveller experience across studies in marketing, psychology, psycholinguistics, aesthetics and other related areas. However, from an economic and marketing perspective, the works of Oh et al. (2007), Berry et al. (2002), Lewis and Chambers (2000), Schmitt (1999), Gupta and Vijic (1999), Pine and Gilmore (1998, 1999) and Holbrook and Hirschman (1982) have made significant contributions in explaining the concept of experience (Table 1). Basing their study on an 
extensive review of past literature from the travel and tourism industry, Walls et al. (2011) consider traveller experience as a multidimensional construct that results from an inter-action of internal factors, such as emotion and cognition of the traveller, and external factors, such as human interactions (e.g. with employees), physical experiences and situa-tional factors. Influenced by internal factors, while considering a consumption experience or in the aftermath of a consumption experience the traveller forms his own subjective reality, which may be different from the objective reality portrayed by the product or service consumed. On the other hand, firms may use external factors such as employee interactions and physical experiences to influence the senses of the traveller and thereby influence the way the traveller frames the consumption experience.

Studies related to the prospective view have looked at customer experience as the customer's expectation from a sensory engagement with the experience product or experiential interaction they are about to have. Although very limited studies have been undertaken to define customer experience from the prospective view, this body of literature sees customer sensation and memorabilia created in anticipating encounters as a possible experience product or service. Prospective experience is also created within the consumer from the expectation of the co-creation of experience product (Carù \& Cova, 2003; Prahalad \& Ramaswamy, 2004). Schlosser (2006) defined experience as something that creates expec-tations in the consumer of having a memorable event through involvement that might demand attention. Such prospective definitions are also provided by researchers such as Lashley (2008), Mossberg (2007) and Andersson (2007), who define customer experience in the context of hospitality and tourism, where travellers involve themselves in the creation of memory and engaging emotions (Zakrisson \& Zillinger, 2012).

Table 1. Studies grouping on the definition of experience.

\begin{tabular}{|c|c|c|}
\hline Authors & Definition & $\begin{array}{l}\text { Prospective/ } \\
\text { reflective }\end{array}$ \\
\hline Oh et al. (2007) & $\begin{array}{l}\text { From a consumer's perspective, experiences are } \\
\text { "enjoyable, engaging, memorable encounters for those } \\
\text { consuming these events" }\end{array}$ & Prospective \\
\hline Berry et al. (2002) & $\begin{array}{l}\text { The means of orchestrating all the clues that people detect } \\
\text { in the buying process }\end{array}$ & Reflective \\
\hline $\begin{array}{l}\text { Lewis and Chambers } \\
\text { (2000) }\end{array}$ & $\begin{array}{l}\text { The total outcome to the customer from the combination } \\
\text { of environment, goods and services purchased }\end{array}$ & Reflective \\
\hline Schmitt (1999) & $\begin{array}{l}\text { Experiences are private events that are not self-generated } \\
\text { but rather occur in response to some staged situation } \\
\text { and involve the entire being }\end{array}$ & Reflective \\
\hline $\begin{array}{l}\text { Gupta and Vijic } \\
\text { (1999) }\end{array}$ & $\begin{array}{l}\text { An experience occurs when a customer has any sensation } \\
\text { or knowledge acquisition resulting from some level of } \\
\text { interaction with different elements of a context created } \\
\text { by a service provider }\end{array}$ & Reflective \\
\hline $\begin{array}{l}\text { Pine and Gilmore } \\
\quad(1998,1999)\end{array}$ & $\begin{array}{l}\text { A distinct economic offering that is as different from } \\
\text { services as services are from goods; successful } \\
\text { experiences are those that the customer finds unique, } \\
\text { memorable and sustainable over time, would want to } \\
\text { repeat and build upon, and enthusiastically promotes } \\
\text { via word of mouth }\end{array}$ & Reflective \\
\hline $\begin{array}{l}\text { Holbrook and } \\
\text { Hirschman (1982) }\end{array}$ & $\begin{array}{l}\text { Those facets of consumer behaviour that relate to the } \\
\text { multisensory, fantasy and emotive aspects of one's } \\
\text { experience with products }\end{array}$ & Prospective \\
\hline
\end{tabular}


On the other hand, researchers defining customer experience from a reflective perspective deal with customer experience during or after the consumption of an experience product or sensory interaction (Bos, McCabe, \& Johnson, 2013). Researchers opine that customer experience may happen during the consumption activity or after it has taken place (Tung \& Ritchie, 2011). While a thorough body of research into customer experience during con-sumption exists, very little mention is found of post-consumption customer experience. Oh, Fiore, and Jeoung (2007), Ooi (2005), Puccinelli et al. (2009), Verhoef et al. (2009) and Grewal et al. (2009) provide a review of the existing literature dealing largely with customer experience during consumption. They described the literature on customer experience pri-marily in the context of retailing. Ooi (2005) discusses the existing literature on the basis of macro factors that affect tourism service providers in dealing with customer experience. Literature on the elements of retail drivers that affect customer experience - namely, farm-controlled factors, promotion, price, merchandise, supply chain and location - is dealt with by these researchers in detail.

\section{Creation of customer experience}

Researches found that firms producing experiential products need to look at the antecedents of customers' experience and maintain the balance between the antecedents of the experi-ence with both emotive and cognitive elements (Smith \& Bolton, 2002). Over the length of consumption, consumers undergo different optimums for both cognition and emotion (Lin, 2004). However, whether an experience product will be consumed or not depends on the consumer integrating her cognition and emotion with the product (Yuksel, Yuksel, \& Bilim, 2010).

\section{Antecedents}

Kim (2014) examined the antecedents of memorable tourism experiences and constructed a scale to measure the destination attributes associated with memorable experience. The authors considered 10 dimensional constructs related to destination attributes that create memorable tourism experience. Other researchers (Assaf \& Josiassen, 2012; Beerli \& Martin, 2004; Kim, Hallab, \& Kim, 2012) identified important tourism-related attributes and examine their performance to influence consumer decision. These studies have also shown that tourists' experience in the destination affects the formation of customers' image about the destination.

Verhoef et al. (2009) examined the creation of customer experience from a holistic per-spective by discussing the determinants of customer experience. The authors provide a dynamic view by arguing that past customer experience will have an influence on future customer experience. The study also discusses the importance of social environment, self-service technologies and store brand in creating customer experience in the retail environment, and how experience-based businesses can create growth by focusing on issues such as how and to what extent experience can influence consumers' buying behaviour. Pratt and Aspiunza (2012), Konus, Verhoef, and Neslin (2008) studied customer experience in a multi-channel environment and opined that experience created in one channel may be affected by experiences in other channels. There could thus be interaction between the channels while delivering customer experience. For instance, positive customer experience created online may have a significant effect on the customer's in-store experience (Lan Luo \& Ratchford, 2008). 
The creation of experience differs from the delivery of a service primarily because service is delivered on demand whereas experience is staged (Pine \& Gilmore, 1999). The experience product motivates travellers at an emotional level rather than restricting itself to a merely cognitive level. It is these kinds of goods that create emotional temptation. Lee and Ariely (2006) described experience products as luxury goods that are multisensory and provide experiential consumption, fun, pleasure and memorable events. It was noted that while the consumption behaviour of experience travellers showed large inter-traveller variability in the context of a specific experience attribute (Gill, 2008; Otto $\&$ Ritchie, 1996), the standard service attributes, such as empathy and reliability, did not show such extreme variability. Experience products are more affect-rich and elicit associative imagery, so consumers rely on intuition when choosing them (Frederick, 2005). Hence, the consumption of experience products may be perceived as a more discretionary activity.

\section{Cognitive and emotive components of experience}

The cognitive and emotive aspects of consumption experience are orthogonal to each other (Hirschman \& Holbrook, 1982). During consumption travellers may experience both cog-nition and emotion at very high levels, at an average level, or lower. This indicates that different optimums for travellers may exist for both cognition and emotion. Further, Carù, and Cova (2003) point out that even though a consumption experience could be ordinary or extraordinary, it still involves a flow of thoughts (cognition) and feelings (emotions). Another important aspect of the emotion-cognition criteria is that even though firms try to orchestrate a consumption experience, it is up to the travellers to use their cognition and, specifically, their emotions in experiencing the orchestrated experience (Quan \& Wang, 2004). If travellers do not integrate their cognition and emotion, they can miss the orchestrated experience (Walls et al., 2011).

Researchers such as Ritchie and Hudson (2009), Schmitt (1999) and Berry et al. (2002) suggest that providing satisfactory emotional content in the customer experience may positively influence the buying process. Experience providers can achieve competitive advan-tage by properly balancing cognitive and emotive complements that may offer appealing and enduring experiences to their customers (Ryan, 1997; Terblanche, 2009). Such a com-bination of cognitive and emotive content in an experience product or service generates interaction between the rational and emotional dimensions of the product. Research also supports the proposition that the emotional component in an experience creates an emotion-al connection with the customer (Cetin \& Bilgihan, 2014).

Researchers investigating tourism experience have discussed multiple experiential factors that have an influence on consumer memorability and have an effect on their psychology of memory (Kim, 2010; Tung \& Ritchie, 2011; Hung, Lee, \& Huang, 2014). Kim (2014) opined that autobio-graphical memory, and the processing of information has long term influence in customers' experiential memorabilia. Considerable research investigated different types of memory and the effect of memory performance in emotion-ally arousing stimuli of consumers.

\section{Co-creation of customer experience}

Researchers, albeit a limited number, have investigated the co-creation of experience between (1) the experience provider and customer and (2) customer and customer (Büttgen, Schumann, \& Ates, 2012; Finsterwalder \& Kuppelwieser, 2011; Leavy, 
2012). The co-creation of customer experience typically refers to the traveller's participation in the design, creation and delivery of an experience product (Kirpalany, 2011; Selstad, 2007). In the co-creation process, an individual traveller's engagement in co-creation activities can increase customer experience (Gentile et al., 2007). These researchers found a significant positive effect on the perceived traveller experience as a result of both company and customer co-creation, and customer-to-customer co-creation (Edvardsson, Enquist, \& Johnston, 2005). Hakanen and Jaakkola (2012) found that the effective cocre-ation of a consumption experience requires a fit between the perceptions of experience providers and their participating customers with regard to the core elements of an experi-ence product's attributes, functions and processes, customers' perceptions of their own experience consumption, and the perceived after-effect of a consumption experience (Pra-halad \& Ramaswami, 2004; Sharpley \& Jepson, 2011). Co-creation is affected by, for instance, customers' preferences for participation and value, and the degree of compe-tition, clarity of role division and rapport among suppliers (Kuppelwieser \& Finster-walder, 2011). Hilton (2008) applied service-dominant logic (SD logic) to understand the traveller's experience of service in the context of coproduction. The author examined service organizations' reliance on the operant resources of consumers to co-produce in the context of self-service experiences. The author pointed out that the difficulty in co-cre-ation of experience lies in the limitation of the customer's productivity to gain a competi-tive advantage for the company through reducing cost (Ferguson, Paulin, \& Bergeron, 2010).

\section{Consumption of experience: internal and external experience consumption}

Researchers have investigated the consumption of experience largely from two perspectives: (1) internal experience consumption (Holbrook, 2006; Kim, 2014; Ofir \& Simonson, 2007; Small, Darcy, \& Packer, 2012) and (2) external experience consumption (Grove, Pickett, Jones, \& Dorsch, 2012; Holbrook, 2006; Keh \& Pang, 2010; Ofir \& Simonson, 2007). Internal experience consumption happens when individual travellers consume an experience primarily by themselves. For instance, enjoying a ride in a theme park, watching a movie in a multiplex, skiing in winter and so on are primarily done in a fixed environment and are experienced by individual travellers internally. On the other hand, external experi-ence consumption refers to the enjoyment of an experience product by a group of travellers collectively where there are provisions for interaction between the group members. Custo-mers' experiences during cruise travel or dining in a theme restaurant are examples of exter-nal experience consumption. Investigation has also revealed that in some experiences both internal and external consumption take place. For example, river rafting involves both internal and external experience consumption.

Solomon and Corbit (1974) developed a motivation theory called the standard pattern of affective dynamics. According to this theory, consumption experience can be divided into five phases: (a) the stimulus onset phase, after which the peak of the primary hedonic stage is reached; (b) a period of hedonic or affective adaptation; (c) continuity of the hedonic process at a steady level as long as stimulus intensity is maintained; (d) a peak of affective after-effect which quickly follows stimulus termination and (e) the after-state decay, which disappears overtime. In the first three stages, the consumers reach to the peak of the hedonic stage, adapt the hedonic components of the experience product and then continue consum-ing it for a period of time. In this context, internal experience consumption takes place in the first three stages. As this consumption process continues, the consumers come across the termination of emotive stimulus, primarily due to several agents like presence of better 
stimulus, self-saturation and so on, that follow the last two stages, decay and disappearance of experience.

Grewal et al. (2009) and Parasuraman et al. (1985) opined that delivering the maximum consumption utility of a service to all travellers is a difficult and crucial issue for most service providers. According to these authors, this is primarily because different consumers respond differently to the attributes of services. Consumer utility of a service product varies across consumers and largely depends on the tangible and intan-gible components of the service's features: its price, the service delivery and the consu-mers' perception of the reliability of the service (Sharpley \& Jepson, 2011). In the context of consumption, an experience product is in many ways similar to a service. According to Pine and Gilmore (1999), experience consumption, in a similar way to ser-vices, stimulates different customers differently. An experience product may vary from a mass customized one, such as a holiday cruise or a wedding party, to a fairly standardized one, such as delivering a particular theme or sensory memorabilia (Holbrook \& Hirsch-man, 1982; Jones, Reynolds, \& Arnold, 2006; Kerin, Jain, \& Howard, 1992; Morgan et al., 2009). The potential for maximizing customer satisfaction is therefore high as it relies upon the creativity, skill and personality of the service providers. The linking factors in this case are people, creativity and delivery, and it is these that provide an inse-parable competitive advantage to the producers while affecting the cost structures, pushing them to the higher end (Groth, 1995a, 1995b).

According to Mossberg (2007) and Shugan and Xie (2000), an important aspect of experience consumption (referred to by the author as a "highly intangible service") is the environment in which it is delivered. The environment stimulates the consumer into becom-ing a member of the entire event of consumption and becoming party to it. The authors carried out their research in the context of amusement parks. In their study of hotel ame-nities, Goldberg, Green, and Wind (1984) noted that consumers' utility of highly intangible services (which could be considered experience products as well) depends on their liking of experience-delivering attributes and also on the extent of their engagement with those attri-butes. These authors, as well as several others (Ofir, Raghubir, Brosh, Monroe, \& Heiman, 2008), argue that buyers consume experiences when they interact with the physical environ-ment and with people, with the resulting atmosphere and ambiance creating an experience for consumption.

Hence, an experience can be created for consumption in various settings where travellers interact and involve themselves in the process of creation and consumption. Taking into account the views expressed in the literature on the subject, it is important that the consump-tion of an experience product is treated independently since the experience component pro-vides distinct utility to the travellers. Combining it with the service would conceal the true impact of an experience component on a traveller's preference. The experience products that are offered in amusement parks, restaurants, shops such as Disney, or even in "American Girl shops" have stimuli that are connected to the environment in which the product is offered, and hence a proper identity of the consumption of an experience product is also necessary.

Effect of customer experience: brand perception and buying behaviour

An important aspect of customer experience for marketers to understand is its effect on the performance factors of the company and its brands. The customer experience paradigm engages the customer in a meaningful way that evokes the customer's emotions. Consequently, consumption of experience can drive customers to actions such as high 
brand perception and loyalty (San Martin, Collado, \& Rodriguez del Bosque, 2013), positive buying behaviour, increased consumption and lower price sensitivity, all of which are beneficial for companies (Holbrook, 2006; Roth \& Menor, 2003). Such experience-based behaviour is generated by the traveller's engagement with unique memorable events, novelty and aesthetics, leading them to make positive inferences about the brands they purchase (Price, Arnould, \& Deibler, 1995; Walls et al., 2011). Researchers (Fitzsimons, Chartrand, \& Fitzsimons, 2008; Ofir \& Simonson, 2007) have investigated the influence of experience marketing on travellers' perception of brands. Travellers' brand perception can change significantly on the basis of their experiential interaction with a brand. Studies have shown that a customer's expectation prior to experience consumption has a significant effect on their post-purchase evalu-ation of the performance of the product and brand. O'Dell and Billing (2005), Ambler et al. (2002) investigated the effect of customer experience on brand equity and customer equity. Studies by Rust, Zeithmal, and Lemon (2001) opined that custo-mers' experience and knowledge of a brand have a significant effect on customer-based brand equity.

Researchers using longitudinal data have also studied the dynamic effect of experience on customer satisfaction over a period of time for the same group of customers (Bolton \& Drew, 1991; Boulding, Kalra, Staelin, \& Zelthaml, 1993). These studies are of the opinion that customer experience has a long-term effect on customer satisfaction with a brand. Research also finds that external events that generate a strong positive or negative experi-ence have a significant positive or negative effect on customer satisfaction (Bolton, 1998; Van Doorn \& Verhoef, 2008).

To study the effect of customer experience on brand perception and customer loyalty, researchers (Brakus et al., 2009; Zhang, Agarwal, \& Lucas, 2011) have found a posit-ive relationship between customer experience and brand perception, as well as customer loyalty. Zhang et al. (2011) investigated personalized product recommendations adapted to individual customers' preferences and tastes that can be used by online retailers to enhance customers' shopping experience. Brakus et al. (2009) constructed a brand experience scale with four dimensions: sensory, affective, intellectual and behavioural. These authors showed that brand experience affects consumer satisfaction and loyalty directly and indirectly through brand personality associations.

Among the four brand experience dimensions mentioned above, it was observed that affective brand experience has a positive effect on brand trust and commitment (Oh, Fiore, \& Jeoung, 2007). Mixed results were found in the case of behavioural brand experi-ence, which suggest that it does not meaningfully affect brand trust but positively affects brand commitment (Hee \& Kang, 2012). Research also found that brand trust positively affects brand commitment, and brand relationship quality (trust, commitment) positively influences brand loyalty. While investigating the effect of customer experience on repeat purchasing, researchers investigated how customer experience affects customer satisfaction and, in turn, repurchase intention (Ooi, 2005; Yi \& Gong, 2009). On the foundation of the stimulus-organism-response model, the authors found that perceived customer experience in service delivery influences customer satisfaction, which in turn affects repurchase intention.

\section{Effect of different moderators on customer experience}

In this section we review the existing research on the moderating role of customers' selfcharacteristics, customers' group characteristics and prior experience. 
Customers' self-characteristic moderator: individual's emotional quotient, product knowledge and demography

From the perspective of the marketer, experience must be staged carefully by the appropri-ate design of the tangible environment of the experience. The attributes of that environment may include features such as the comfort of seating at a movie theatre, the ambient music at a restaurant, the offering of memorabilia such as T-shirts and coffee mugs, and the price of the experience. Note that while these attributes are external to the customer, the experience is in the mind of the customer and is thus inherently idiosyncratic (Pine \& Gilmore, 1998). As customers are likely to exhibit considerable variation in their responses to the same con-figuration of attributes, marketers must take such heterogeneity into account as they make a trade-off between the cost and the value added by the experience. A similar challenge is encountered by service providers in general (Grewal et al., 2009; Parasuraman et al., 1985; Prebensen, Woo, \& Uysal, 2014).

Customer experience can vary between individual customers to the extent that they differ in how they perceive, associate and consume experiences due to their individual characteristics. Traveller heterogeneity with regards to gender, socioeconomic and ethnic background, culture and other key demographics impact the way a traveller frames and interprets a consumption experience. According to Holbrook and Hirschman (1982), subculture is an important characteristic that influences how a product or service is viewed by different travellers. Travellers from different subcultures may view the same product with different emotions and fantasies. For example, Protestants are less emotionally charged while Jews are generally more emotionally involved. Holbrook and Hirschman were also of the view that products for experiential consumption also differ by subcultural groups. For example, to an older and wealthier individual with higher social status, going to the opera is more aesthetic than to a younger, less wealthy traveller with lower status.

Adhikari et al. (2013) investigated individuals' preferences and knowledge about experience product attributes that would influence their selection of an experience product. The authors argue that an individual's knowledge about the attributes of an experi-ence product and their preferences about experience products would be heterogeneous. Such individual characteristics would moderate customer experience at an individual level. Banks, Coan, and Gertman (1978) investigated the effect of personalizing customer experience in a service organization by having a member of senior management greet cus-tomers in a "warm, friendly manner". Kamakura and Russell (1989) used a mixed model to account for pricespecific as well as preference-related heterogeneity among customers. They found that ignoring heterogeneity significantly overstates individual taste and prefer-ence (parameter estimates). Krishnamurthi, Mazumder, and Raj (1992) carried out a priori segmentation of travellers who are loyal and those who are switchers and showed that segment-specific estimates are significantly different from aggregate-level estimates.

Consumers' group characteristic moderator: group construction and group interaction

Researchers have studied customer group behaviour in the creation and consumption of experience. They have also studied the influence of other group members on individual consumers' own contribution in the creation of a service experience. These researchers have investigated the moderating effects of customers' group characteristics in terms of both group construction and group interaction (Finsterwalder \& Kuppelwieser, 2011).

Research carried out into the moderating effect of group characteristics on the basis of group construction suggests that group behaviour is significantly related to the charac- 
teristics of group members. Wang (1999) and Kuppelwieser and Finsterwalder (2011) found that the opinions of other group members have a significant effect on a traveller's contribution to the co-creation and consumption of a service experience. The study looked at two groups of services: sport and other leisure experience. Their study shows that group behaviour moderates the performance of individual members in a group in cocreating and consuming experience. Johnson, Garbarino, and Sivadas (2006) investigated whether differences in loyalty, risk perception and category experi-ence can explain customer groups having two different views, for instance being both critical and lenient in their satisfaction rating.

Researchers studying the effect of group interaction on moderating customer experience have opined that group interaction has a significantly different effect on a purchase decision compared to a decision taken solely by an individual (Grove \& Fisk, 1997). Adhikari and Rao (2013) investigated consumers' decision-making on the selection of restaurant service in both the individual and family contexts. These researchers showed that different utility functions exist for individual members of the family and the family as a whole. O'Connell (2006) explained how waiters observe and continuously access the group dynamics, body language and behaviour of their guests. They sub-sequently pass on this information to staff who render services directly to individual con-sumers. The author opined that interaction between group members elevates the mood rating of the group. The decision made by consumers on the consumption of an experi-ence product is often made jointly in a group. This interaction will be influenced by the preference structure of individual members of the group (Foxman, Tansuhaj, \& Ekstrom, 1989), and consumption will take place accordingly. At the same time, it is very likely that an individual will have different preferences when an experience product is consumed jointly rather than individually (Davis, 1973). Researchers have dis-covered that customer interaction has a profound effect on customer experience (Tsiros \& Parasuraman, 2006; Williams, 2006). Marketing literature has rarely addressed the issue of marketers creating experience through interaction between customers, and has primarily focused on marketers' interaction with customers (Vehroef et al., 2009). Studies have found that consumers in groups can affect each other during their interaction (Baker, 1987), which consequently has an effect on their experience consumption (Martin \& Pranter, 1989; Wu, 2007).

\section{Prior experience moderators}

Adaptation-level theory (Helson, 1964) suggests that people judge a stimulus based on the level to which they have become adapted. Hence, in the context of experience marketing, a traveller's experience-based reference of previous encounters with different marketing mix variables operates in forming the adaptation level against which present and future experience stimuli are judged by the travellers (San Martin, Collado, J., \& Rodriguez del Bosque, I. (2013). Uriely (2005) focused on the importance of prior customer experience in the context of store environment, service encounter and store brand on the customer's future experience. Several researchers (Hung, Lee, \& Huang, 2014; Rodríguez Molina, Frias-Jamilena, \& Castaneda-Garcia, 2013) have investigated the moderating effects of previous product and brand experience, price experience, promotion experience and supply chain management experience on travellers' buying behaviour and future experience consumption. We synthesize this body of literature below. 
Previous product and brand experience

Mantrala et al. (2009) provided a framework for retailers' trade-offs on the basis of consumers' perceptions and preferences. An examination of previous research shows that these authors opine that predicting customer perception is difficult in the context of product and brand assortment in the retail environment. This is because a large array of products in a particular product category provides adequate flexibility to consumers who, in turn, are unable to distinguish between the experiences on offer from different brands during pur-chase. Puccinelli et al. (2009) opined that a larger assortment of brands causes consumers to change their goal, so they may not buy their first choice product. Several researchers have examined the ideal number of stock keeping units that a retailer should carry in a category to provide a positive experience for consumers (Bultez \& Naert, 1988).

Some research has also been conducted to capture customer experience from prior product consumption. Neslin et al. (2006) investigated the impact on customer experience, which evolves over time from beginning to purchase and, finally, to consumption of the product. Hence it is important to consider the dynamics of consumer experience consump-tion where prior product experience plays a critical moderating role in the future experi-ences of consumers. Longitudinal studies carried out into customer satisfaction (Boulding et al., 1993) have shown that previous customer experience of product perform-ance is a strong predictor of current customer satisfaction. This suggests that previous product experience has a strong effect on a consumer's perception of the present experience (Anderson, Pearo, \& Widener, 2008).

\section{Previous price experience}

A substantial body of research evidence is available in the marketing literature in which pre-vious price experiences are used as a reference by consumers in their current experience. Fox and Sethuraman (2006) opined that consumers shopping for the same merchandise at different times can usually distinguish the pricing strategy of the retailers. Many retailers use everyday low pricing strategies and high/low pricing strategies where previous price experience has an effect on what the consumer is willing to pay in future (Kang, Stein, Heo, \& Lee, 2012). Mazumdar, Raj, and Sinha (2005) studied the reference price effect on consumers' willingness to pay. They suggested that a common conceptualization views a previous price experience as a predictive price expectation that is shaped by the consumer's prior experience and current purchase environment (Briesch, Krishnamurthi, Mazumdar, \& Raj, 1997). Researchers have studied competitive behaviour in considering reference price effects, suggesting managerial practices for retail outlets (Greenleaf \& Lehmann, 1995), as well as the behavioural perspectives of reference price formulation and their effect on consumer decision-making for future purchases (Briesch et al., 1997; Winer, 1986).

\section{Previous promotion experience}

Researchers have extensively studied the effect of promotion in different marketing contexts. A section of this research has also studied the value that marketing promotion provides to the experience of individual customers or groups of customers in the retail context (Fox \& Hoch, 2005). Mela, Gupta, and Lehmann (1997) studied the distinction between the short- and longterm performances of promotion and communication depending upon their effectiveness over a longer time. Several researchers have studied commonly used techniques in promotion, namely deep discount deals (price promotion), flyers and in-store displays (adver-tising promotion) and complimentary products (product promotion), and their effects on the customer retail experience. Sun (2005) found that there is significant brand switching and 
store-level switching as a result of customers' previous promotion experiences. Studies have found that promotion not only increases the sales of promoted items but also increases sales of other items due to higher customer footfall in retail outlets (Walters \& MacKenzie, 1988).

Proposed gap in the literature of customer experience and avenue for future research

Although the marketers of tourism services recognized the importance of creating and delivering travellers' experience, the academic literature researching different facets of consu-mer experience is limited. Our review found the existence of literature on consumer experience in hospitality and tourism industry in a very limited way. In this section, we identify the several gaps in the literature of customer experience which would pave the avenue of future research in the area of consumer experience in tourism industry.

Most notably, the literature identifying different constructs to measure consumer experi-ence in hospitality and tourism industry is limited. Researchers sometimes have used con-structs measuring customer's satisfaction and service quality to measure consumer experience; however, this review showed that there is fundamental difference between factors measuring service and experience. In order to identify and develop an experiential consumption, the practitioners need to know how the customer experience can be measured that would capture all facets of consumption experience in tourism industry. It is also impor-tant to investigate the impact of relevant drivers of consumer experience on consumer decision-making.

Another aspect of consumer experience in hospitality and tourism industry that needs attention is the interaction of social environment in developing and delivering consumer experience. For example, how experiences create group bargaining and group influence in consumer decision-making has not received any attention by the researchers investigating the phenomena in tourism industry. While there is some literature investigating the interaction between the service provider and the consumer, between-customer interactions is rarely present in the extant literature reviewed in this article. Considering the rapid increase of consumer interaction through social websites (Rihova, Buhalis, Moital, \& Gouthro, 2014; Rihova, Buhalis, Moital, \& Beth Gouthro, 2013), most contemporary area of research could be how companies look at building and maintaining interconsumer interaction to enhance the consumption of experience product.

Although we could find literature on online shopping experience, this body of literature has looked at determinants of customer online interactions to use technology in the consumption process. We found negligible literature that has examined the impact of technology-based systems on customer experience. We also have not found any literature that has examined technology as a mediator in experience consumption. Considering that technol-ogyenabled consumption environment would become very popular in hospitality and tourism sector of emerging as well as developed countries, insights on how and to what extent technology-based systems influence consumers' overall experience are crucial. For example, how the selection of tourism destination based on online information mediates travellers' experience may be relevant to examine. Another area of research could be to derive an ideal combination of employee and technology to optimize consumption

experience and to what extent consumers should be active in interacting with self-service as well as service assistant could be another avenue of research. 
In this article we have structured the theoretical underpinnings of the marketing of customer experience and proposed a conceptual framework to explain different aspects of customer experience. We have synthesized literature that gives insight and direction into an under-standing of customer experience from the consumption of an experience product as well as interaction with sensory memorabilia. As summarized in the framework, we have divided experience into either pure experience or a mixture of experience attributes and tan-gible goods or intangible services. This would help the marketer to categorize the customer experience in a more meaningful way than considering it as an overall marketing phenom-enon, as previous researchers have done .

While studying experience as sensory interaction, we have not considered online customer experience literature in great detail as fairly respectable work in this area has already been done by Rose et al. (2010). However, we have referred to some relevant literature in this context while explaining the online environment in relation to experience interaction with customers. This article has also grounded literature on the effect of environ-ment and thereby identifying consumers' interaction with the environment during consumption.

Our proposed framework suggests that customer experience is a combination of cogni-tive and affective components, the positive representation of which has a positive impact on customers' future experiences. It relates three main aspects of consumer experience: antecedents, creation and consumption of experience, and effect of customer experience. We have studied a diverse body of literature in this context, explaining a number of cognitive and affective factors that create customer experience. It should be noted that the framework is conceptual, and the empirical study may help in reinforcing academic understanding in the area of marketing and customer experience. In dealing with the consumption of custo-mer experience we have addressed the issue from the perspective of two extremely relevant conditions of customer experience consumption: that is, internal experience consumption and external experience consumption. In describing literature on experience consumption, we have synthesized the literature in internal and external consumption where individual's as well as group's experience consumption is separately described. This will help the mar-keters to appreciate different types of consumption process for the individual and the group separately, and accordingly design the product. In our opinion, this demarcation of experi-ence consumption would help practitioners to understand the key factors to be considered for the development of experience memorabilia for their customers. The well-defined understanding of customers' experience consumption could also give academics a new area of research. In studying the effects of customer experience, we have tried to make some headway in terms of synthesizing literature on the effects of customer experience on customers' price sensitivity, brand perception and loyalty. However, we believe that there is a need to extend research in this area of study. 


\section{References}

Adhikari, A. (2014). Differentiating subjective and objective features of experience product to estimating price premium. Journal of Travel Research. doi:10.1177/0047287514532366

Adhikari, A., Basu, A., \& Raj, S. P. (2013). Pricing of experience products under consumer heterogeneity. International Journal of Hospitality Management, 33, 6-18.

Adhikari, A., \& Rao Arza, K. (2013). Individual preference and bargaining behavior in families' buying decisions of restaurant service. Cornell Hospitality Quarterly, 54(3), 248-261.

Agapito, D., Mendes, J., \& Valle, P. (2013). Exploring the conceptualization of the sensory dimension of tourist Experiences. Journal of Destination Marketing \& Management, 2(2), 62-73.

Aho, S. K. (2001). Towards a general theory of touristic experiences: Modelling experience process in tourism. Tourism Review, 56(3/4), 33-37.

Ambler, T., Bhattacharya, C. B., Edell, J., Keller, K. L., Lemon, K. N., \& Mittal, V. (2002). Relating brandand customer perspectives on marketing management. Journal of Service Research, 5(1), 13-25.

Anderson, S., Pearo, L. K., \& Widener, S. K. (2008). Drivers of service satisfaction: Linking customer satisfaction to the service concept and customer characteristics. Journal of Service Research, 10(4), 365-381.

Andersson, T. (2007). The tourist in the experience economy. Scandinavian Journal of Hospitality and Tourism, 7(1), 46-58.

Arnold, E., \& Price, L. L. (1993). River magic: Extraordinary experience and extended service. Journal of Consumer Research, 20, 24-45.

Arnold, M. J., Reynolds, K. E., Ponder, N., \& Lueg, J. E. (2005). Customer delight in a retail context: Investigating delightful and terrible shopping experiences. Journal of Business Research, 58(8), 1132-1145.

Arora, R. (2012). A mixed method approach to understanding the role of emotions and sensual delight in dining experience. Journal of Consumer Marketing, 29(5), 333-343.

Assaf, A. G., \& Josiassen, A. (2012). European vs. US airlines: Performance comparison in a dynamic market. Tourism Management, 33(2), 317-326.

Baker, J. (1987). The role of the environment in the marketing service: The consumer perspective. In J. A. Czepiel, C. A. Congram, \& J. Shanahan (Eds.), The services challenge: Integrating for competitive advantage (pp. 79-84). Chicago, IL: American Marketing Association.

Baker, J., Parasuraman, A., Grewal, D., \& Voss, G. B. (2002). The influence of multiple store environ-ment cues on perceived merchandise value and patronage intentions. Journal of Marketing, 66(2), 120-141.

Banks, W. W., Coan, G.Jr., \& Gertman, D. (1978). Manager effect on consumer behavior: An unob-trusive assessment. American Journal of Small Business, 3(1), 18-24.

Baron, S., Harris, K., \& Davies, B. J. (1996). Oral participation in retail service delivery: A compari-son of the roles of contact personnel and customers. European Journal of Marketing, 30(9), 75-90.

Beerli, A., \& Martin, J. D. (2004). Factors influencing destination image. Annals of tourism research, 31(3), 657-681.

Berry, L. L., Carbone, L. P., \& Haeckel, S. H. (2002). Managing the total customer experience. MIT Sloan Management Review, 43(3), 85-89.

Binkhorst, E., \& Den Dekker, T. (2009). Agenda for co-creation tourism experience. Journal of Hospitality Marketing \& Management, 18(2), 311-327.

Bitner, M. J. (1992). Servicescapes: The impact of physical surroundings on customers and employees. Journal of Marketing, 56(2), 57-71.

Bolton, R. N. (1998). A dynamic model of the duration of the customer's relationship with a continu-ous service provider: The role of satisfaction. Marketing science, 17(1), 45-65.

Bolton, R. N., \& Drew, J. H. (1991). A multistage model of customers' assessments of service quality and value. Journal of Consumer Research, 17(4), 375-384.

Bos, L., McCabe, S., \& Johnson, S. (2013). Learning never goes on holiday: An exploration of social tourism as a context for experiential learning. Current Issues in Tourism. doi:10.1080/13683500. 2013.790878

Boulding, W., Kalra, A., Staelin, R., \& Zelthaml, V. A. (1993). A dynamic process model of service quality: From expectations to behavioral intentions. Journal of marketing research, 30(1), 7-27.

Brakus, J. J., Schmitt, B. H., \& Zarantonello, L. (2009). Brand experience: What is it? How is it measured? Does it affect loyalty? Journal of Marketing, 73, 52-68. 
Brakus, J. J., Schmitt, B. H., \& Zhang, S. (2008). Experiential attributes and consumer judgments. In B. H. Schmitt \& D. Rogers (Eds.), Handbook on brand and experience management (pp. 174- 187) Northampton, MA: Edward Elgar.

Bramwell, B., \& Rawding, L. (1994). Tourism marketing organizations in industrial cities: Organizations, objectives and urban governance. Tourism Management, 15(6), 425-434.

Briesch, R. A., Krishnamurthi, L., Mazumdar, T., \& Raj, S. P. (1997). A comparative analysis of refer-ence price models. Journal of Consumer Research, 24(2), 202-214.

Büttgen, M., Schumann, J. H., \& Ates, Z. (2012). Service locus of control and customer coproduction: The role of prior service experience and organizational socialization. Journal of Service Research, 15(2), 166-181.

Bultez, A., \& Naert, P. (1988). SH. ARP: Shelf allocation for retailers' profit. Marketing Science, 7(3), 211-231.

Carù, A., \& Cova, B. (2003). Revisiting consumption experience: A more humble but complete view of the concept. Marketing Theory, 3(2), 267-286.

Cetin, G., \& Bilgihan, A. (2014). Components of cultural tourists' experiences in destinations. Current Issues in Tourism. doi:10.1080/13683500.2014.994595

Chang, S., Stansbie, P., \& Rood, A. S. (2014). Impulsive consumption in the experiential context. Current Issues in Tourism, 17(2), 145-163.

Chattopadhyay, A., \& Laborie, J. L. (2005). Managing brand experience: The market contact audit ${ }^{\mathrm{TM}}$. Journal of Advertising Research, 45(1), 9-16.

Chen, M. H. (2007). Macro and non-macro explanatory factors of Chinese hotel stock returns. International Journal of Hospitality Management, 26(4), 991-1004.

Cohen, E. (1979). A phenomenology of tourism experiences. Sociology, 13, 179-201.

Connell, J., \& Meyer, D. (2004). Modelling the visitor experience in the gardens of Great Britain. Current Issues in Tourism, 7(3), 183-216.

Cutler, S., \& Carmichael, B. (2010). The dimensions of the tourist experience. In M. Morgan, L. Lugosi, \& J. R. B. Ritchie (Eds.), The tourism and leisure experience: Consumer and managerial perspectives (pp. 3-26). Bristol: Channel View Publications.

Daugstad, K. (2008). Negotiating landscape in rural tourism. Annals of Tourism Research, 35(2), $402-426$.

Davis, J. H. (1973). Group decision and social interaction: A theory of social decision schemes. Psychological Review, 80(2), 97-125.

Edvardsson, B., Enquist, B., \& Johnston, R. (2005). Cocreating customer value through hyperreality in the prepurchase service experience. Journal of Service Research, 8(2), 149-161.

Ellis, G. D., \& Rossman, J. R. (2008). Creating value for participants through experience staging: Parks, recreation, and tourism in the experience industry. Journal of Park and Recreation Administration, 26(4), 1-20.

Feng, K., \& Page, S. J. (2000). An exploratory study of the tourism, migration-immigration nexus: Travel experiences of Chinese residents in New Zealand. Current Issues in Tourism, 3(3), 246281.

Ferguson, R. J., Paulin, M., \& Bergeron, J. (2010). Customer sociability and the total service experi-ence: Antecedents of positive word-of-mouth intentions. Journal of Service Management, 21(1), 25-44.

Finn, A. (2005). Reassessing the foundations of customer delight. Journal of Service Research, 8(2), 103-116.

Finsterwalder, J., \& Kuppelwieser, V. G. (2011). Co-creation by engaging beyond oneself: The influ-ence of task contribution on perceived customer-to-customer social interaction during a group service encounter. Journal of Strategic Marketing, 19(7), 607-618.

Fitzsimons, G. M., Chartrand, T. L., \& Fitzsimons, G. J. (2008). Automatic effects of brand exposure on motivated behavior: How apple makes you "think different". Journal of Consumer Research, 35(1), 21-35.

Fluker, M., \& Turner, L. (2000). Needs, motivations, and expectations of a commercial whitewater rafting experience. Journal of Travel Research, 38(4), 380-389.

Fox, E. J., \& Hoch, S. J. (2005). Cherry-picking. Journal of Marketing, 69(1), 46-62.

Fox, E. J., \& Sethuraman, R. (2006). Retail competition. In Retailing in the 21st Century (pp. 193208). Berlin: Springer.

Foxman, E. R., Tansuhaj, P. S., \& Ekstrom, K. M. (1989). Family members' perceptions of adolescents' influence in family decision making. Journal of Consumer Research, 15(4), 482-491. 
Frederick, S. (2005). Cognitive reflection and decision making. Journal of Economic perspectives, 19(4), 25-42

Gentile, C., Spiller, N., \& Noci, G. (2007). How to sustain the customer experience: An overview of experience components that co-create value with the customer. European Management Journal, 25(5), 395-410.

Gill, C. (2008). Restoring consumer confidence in financial services. International Journal of Bank Marketing, 26(2), 148-152.

Gilmore, J. H., \& Pine, J. (2002a). Differentiating hospitality operations via experiences why selling services is not enough. The Cornell Hotel and Restaurant Administration Quarterly, 43(3), 87-96.

Gilmore, J. H., \& Pine, II, J. P. (2002b). Customer experience places: The new offering frontier. Strategy \& Leadership, 30(4), 4-11.

Goldberg, S. M., Green, P. E., \& Wind, Y. (1984). Conjoint analysis of price premiums for hotel amenities. Journal of Business, 57(1), S111-S132.

Grant, R., Clarke, R. J. \& Kyriazis, E. (2007). A review of factors affecting online consumer search behaviour from an information value perspective. Journal of Marketing Management, 23(5-6), 519-533.

Greenleaf, E. A., \& Lehmann, D. R. (1995). Reasons for substantial delay in consumer decision making. Journal of Consumer Research, 22(2), 186-199.

Gretzel, U., \& Fesenmaier, D. (2003). Experience-based internet marketing: An exploratory study of sensory experiences associated with pleasure travel to the Midwest United States. In A. Frew, M. Hitz, \& P. O'Connor (Eds.), Information and communication technologies in tourism (pp. 49-57). Vienna: Springer Verlag.

Grewal, D., Levy, M., \& Kumar, V. (2009). Customer experience management in retailing: An orga-nizing framework. Journal of Retailing, 85(1), 1-14.

Groth, J. (1995a). Exclusive value and the pricing of services. Management Decision, 33(8), 22-29.

Groth, J. (1995b). Important factors in the sale and pricing of services. Management Decision, 33(7), 29-34.

Grove, S. J., \& Fisk, R. P. (1997). The impact of other customers on service experiences: A critical incident examination of "getting along". Journal of Retailing, 73(1), 63-85.

Grove, S. J., Pickett, G. M., Jones, S. A., \& Dorsch, M. J. (2012). Spectator rage as the dark side of engaging sport fans: Implications for service marketers. Journal of Service Research, 15(1), 3-20.

Gupta, S., \& Vijic, M. (1999). The context well and dialectical nature of experiences. In J. Fitzsimmons \& M. Fitzsimmons (Eds.), New service development (pp. 33-51). Thousand Oaks, CA: Sage.

Hakanen, T., \& Jaakkola, E. (2012). Co-creating customer-focused solutions within business networks: A service perspective. Journal of Service Management, 23(4), 593-611.

Haven-Tang, C., \& Jones, E. (2010). Delivering quality experiences for sustainable tourism development: Harnessing a sense of place in Monmouthshire. In M. Morgan, L. Lugosi, \& J. R. B. Ritchie (Eds.), The tourism and leisure experience: Consumer and managerial perspectives (pp. 163-181). Bristol: Channel View Publications.

Heath, E., \& Wall, G. (1991). Marketing tourism destinations: A strategic planning approach. New York: John Wiley \& Sons, Inc.

Hee, J. L., \& Kang, M. S. (2012). The effect of brand experience on brand relationship quality. Academy of Marketing Studies Journal, 16(1), 87-98.

Heimtun, B., \& Abelsen, B. (2012). The tourist experience and bonding. Current Issues in Tourism, $15(5), 425-439$.

Helson, H. (1964). Current trends and issues in adaptation-level theory. American Psychologist, 19(1), 26-38.

Hilton, T. (2008). Leveraging operant resources of consumers: Improving consumer experiences or productivity? The Marketing Review, 8(4), 359-366.

Hirschman, E. C., \& Holbrook, M. B. (1982). Hedonic consumption: Emerging concepts, methods and propositions. The Journal of Marketing, 46(3), 92-101.

Holbrook, M. B. (2006). Consumption experience, customer value, and subjective personal introspection: An illustrative photographic essay. Journal of Business Research, 59(6), 714-725.

Holbrook, M. B., \& Hirschman, E. C. (1982). The experiential aspects of consumption: Consumer fantasies, feelings, and fun. Journal of Consumer Research, 9, 132-140.

Holt Douglas, B. (1995). How consumers consumes: A typology of consumption practices. Journal of Consumer Research, 22, 1-16. 
Hopkinson, G. C., \& Pujari, D. (1999). A factor analytic study of the sources of meaning in hedonic consumption. European Journal of Marketing, 33(3-4), 273-294.

Huffman, C., \& Houston, M. J. (1993). Goal-oriented experiences and the development of knowledge. Journal of Consumer Research, 20, 190-207.

Huffman, C., \& Kahn, B. E. (1998). Variety for sale: Mass customization or mass confusion?. Journal of Retailing, 74(4), 491-513.

Hung, W. L., Lee, Y. J., \& Huang, P. H. (2014). Creative experiences, memorability and revisit inten-tion in creative tourism. Current Issues in Tourism. Advance online publication. doi:10.1080/ 13683500.2013.877422.

Jafari, J., Pizam, A., \& Przeclawski, K. (1990). A sociocultural study of tourism as a factor of change. Annals of Tourism Research, 17(3), 469-472.

Janakiraman, N., Meyer, R. J., \& Morales, A. C. (2006). Spillover effects: How consumers respond to unexpected changes in price and quality. Journal of Consumer Research, 33, 361-369.

Jennings, G., \& Nickerson, N. (Eds.). (2006). Quality tourism experiences. Oxford: Elsevier.

Johnson, M. S., Garbarino, E., \& Sivadas, E. (2006). Influences of customer differences of loyalty, perceived risk and category experience on customer satisfaction ratings. International Journal of Market Research, 48(5), 601-622.

Jones, M. A., Reynolds, K. E., \& Arnold, M. J. (2006). Hedonic and utilitarian shopping value: investigating differential effects on retail outcomes. Journal of Business Research, 59(9), 974-981.

Joy, A., \& Sherry, J. F. (2003). Speaking of arts as embodied imagination: A multisensory approach to understanding aesthetic experience. Journal of Consumer Research, 20, 259-282

Kaltcheva, V. D., \& Weitz, B. A. (2006). When should a retailer create an exciting store environment? Journal of Marketing, 70(1), 107-118.

Kamakura, W. A., \& Russell, G. J. (1989). A probabilistic choice model for market segmentation and elasticity structure. Journal of Marketing Research, 26(4), 379-390.

Kang, K. H., Stein, L., Heo, C. Y., \& Lee, S. (2012). Consumers' willingness to pay for green initiatives of the hotel industry. International Journal of Hospitality Management, 31(2), 564572.

Kastenholz, E., Carneiro, M. J., Peixeira Marques, C., \& Lima, J. (2012). Understanding and managing the rural tourism experience - the case of a historical village in Portugal. Tourism Management Perspectives, 4, 207-214.

Kastenholz, E., Davis, D., \& Paul, G. (1999). Segmenting tourism in rural areas: The case of North and Central Portugal. Journal of Travel Research, 37(4), 353-363.

Kastenholz, E., \& Lima, J. (2011). The integral rural tourism experience from the tourist's point of view: A qualitative analysis of its nature and meaning. Tourism \& Management Studies, 7, 62-74.

Kaynama, S. A., \& Black, C. I. (2000). A proposal to assess the service quality of online travel agencies: An exploratory study. Journal of Professional Services Marketing, 21(1), 63-88.

Keh, H. T., \& Pang, J. (2010). Customer reactions to service separation. Journal of Marketing, 74(2), 55-70.

Kerin, R. A., Jain, A., \& Howard, D. J. (1992). Store shopping experience and consumer pricequality-value perceptions. Journal of Retailing, 68(4), 376.

Khalifa, M., \& Liu, V. (2003). Determinants of successful knowledge management programs. Electronic Journal on Knowledge Management, 1(2), 103-112.

Khalifa, M., \& Liu, V. (2007). Online consumer retention: Contingent effects of online shopping habit and online shopping experience. European Journal of Information Systems, 16, 780-792.

Kim, J. H. (2010). Determining the factors affecting memorable nature of travel experiences. Journal of Travel and Tourism Marketing, 27(8), 780-796.

Kim, S. (2012a). Audience involvement and film tourism experiences: Emotional places, emotional experiences. Tourism Management, 33(2), 387-396.

Kim, S. (2012b). A cross-cultural study of on-site film-tourism experiences among Chinese, Japanese, Taiwanese and Thai visitors to the Daejanggeum Theme Park, South Korea. Current Issues in Tourism, 15(8), 759-776.

Kim, J. H. (2014). The antecedents of memorable tourism experiences: The development of a scale to measure the destination attributes associated with memorable experiences. Tourism Management, 44, 34-45.

Kim, K., Hallab, Z., \& Kim, J. N. (2012). The moderating effect of travel experience in a destination on the relationship between the destination image and the intention to revisit. Journal of Hospitality Marketing \& Management, 21(5), 486-505 
Kim, J. H., \& Ritchie, J. B. (2014). Cross-cultural validation of a memorable tourism experience scale (MTES). Journal of Travel Research, 53(3), 323-335.

Kirpalany, N. (2011). Motivation and goal: Goal-theoretic perspectives of consumer suspicion in value co-creation. AMA Summer Educators Conference Proceedings, 22, 224-225.

Klaus, P. (2013). The case of Amazoncom: Towards a conceptual framework of online customer service experience (OCSE) using the Emerging Consensus Technique (ECT). Journal of Services Marketing, 27(6), 2-2.

Konus, U., Verhoef, P. C., \& Neslin, S. A. (2008). Multichannel shopper segments and their covariates. Journal of Retailing, 84(4), 398-413.

Krishnamurthi, L., Mazumdar, T., \& Raj, S. P. (1992). Asymmetric response to price in consumer brand choice and purchase quantity decisions. Journal of Consumer Research, 19(3), 387-400.

Kuppelwieser, V. G., \& Finsterwalder, J. (2011). Psychological safety, contributions and service sat-isfaction of customers in group service experiences. Managing Service Quality: An International Journal, 21(6), 617-635.

Kwortnik, R. J., \& Thompson, G. M. (2009). Unifying service marketing and operations with service experience management. Journal of Service Research, 11(4), 389-406.

Lane, B. (2009). Rural tourism: An overview. In T. Jamal \& M. Robinson (Eds.), The SAGE handbook of tourism studies (pp. 354-370). London: Sage Publications.

Lan Luo, P. K. K., \& Ratchford, B. (2008). Incorporating subjective characteristics in product design and evaluations. Journal of Marketing Research, 45(2), 182-194.

Lashley, C. (2008). Studying Hospitality: Insights from Social Sciences. Scandinavian Journal of Hospitality and Tourism, 8(1), 69-84.

Leavy, B. (2012). Collaborative innovation as the new imperative-design thinking, value cocreation and the power of "pull". Strategy \& Leadership, 40(2), 25-34.

Lee, G.-G., \& Lin, H.-F. (2005). Customer perceptions of e-service quality in online shopping. International Journal of Retail \& Distribution Management, 33(2), 161-176.

Lee, L., \& Ariely, D. (2006). Shopping goals, goal concreteness, and conditional promotions. Journal of Consumer Research, 33(1), 60-70.

Lewis, R. C., \& Chambers, R. E. (2000). Marketing leadership in hospitality. New York, NY: John Wiley.

Lin, I. Y. (2004). Evaluating a servicescape: The effect of cognition and emotion. International Journal of Hospitality Management, 23(2), 163-178.

Loiacono, E. T., Watson, R. T., \& Goodhue, D. L. (2002). WEBQUAL: A measure of website quality. American Marketing Association Conference Proceedings, 13, 432-438.

Mantrala, M. K., Levy, M., Kahn, B. E., Fox, E. J., Gaidarev, P., \& Dankworth, P. (2009). Why is assortment planning so difficult for retailers? A Framework and Research Agenda. Journal of Retailing, 85(1), 71-83.

Markwell, K. (2001). "An intimate rendezvous with nature"? Mediating the tourist-nature experience at three tourist sites in Borneo. Tourist Studies, 1(1), 39-57.

Martin, C. L., \& Pranter, C. A. (1989). Compatibility management: Customer-to-customer relationships in service environments. Journal of Services Marketing, 3(3), 5-15.

Mazumdar, T., Raj, S. P., \& Sinha, I. (2005). Reference price research: Review and propositions. Journal of Marketing, 69(4), 84-102.

McGinnis, L. P., Gentry, J. W., \& Gao, T. T. (2012). Antecedents to consumer perceptions of sacred-ness in extended service experiences the case of Golf. Journal of Service Research, 15(4), 476- 488.

Mela, C. F., Gupta, S., \& Lehmann, D. R. (1997). The long-term impact of promotion and advertising on consumer brand choice. Journal of Marketing Research, 34(2), 248-261.

Meyer, C., \& Schwager, A. (2007). Understanding customer experience. Harvard Business Review, $85(2), 117-126$.

Michelli, J. (2007). The starbucks experience: 5 Principles for turning ordinary into extraordinary. New York, NY: McGraw Hill.

Middleton, M. (2011). Exploring space, the senses and sensitivities: Spatial knowing. In R. Sharpley \& P. Stone (Eds.), Tourist experience: Contemporary perspectives (pp. 215-226). Oxon: Routledge.

Morgan, M. (2010). The experience economy 10 years on: Where next for experience management? In M. Morgan, L. Lugosi, \& J. R. B. Ritchie (Eds.), The tourism and leisure experience: Consumer and managerial perspectives (pp. 218-230). Bristol: Channel View Publications. 
Morgan, M., Elbe, J., \& de Esteban Curiel, J. (2009). Has the experience economy arrived? The views of destination managers in three visitor-dependent areas. International Journal of Tourism Research, 11(2), 201-216.

Mossberg, L. (2007). A marketing approach to the tourist experience. Scandinavian Journal of Hospitality and Tourism, 7(1), 59-74.

Naylor, G., Kleiser, S. B., Baker, J., \& Yorkston, E. (2008). Using transformational appeals to enhance the retail experience. Journal of Retailing, 84(1), 49-57.

Neslin, S. A., Grewal, D., Leghorn, R., Shankar, V., Teerling, M. L., Thomas, J. S., \& Verhoef, P. C. (2006). Challenges and opportunities in multichannel customer management. Journal of Service Research, 9(2), 95-112.

Neuhofer, B., Buhalis, D., \& Ladkin, A. (2012). Conceptualising technology enhanced destination experiences. Journal of Destination Marketing \& Management, 1(1-2), 36-46.

Novak, T. P., Hoffman, D. L., \& Yong, Y.-F. (2000). Measuring the customer experience in online environments: A structural modeling approach. Marketing Science, 19(1), 22-42.

O'Connell, P. (2006). Taking the measure of mood. Harvard Business Review, 84(3), 25-26.

O'Dell, T., \& Billing, P. (2005). Experiencescapes: Tourism, culture and economy. Frederiksberg: Copenhagen Business School Press.

Ofir, C., Raghubir, P., Brosh, G., Monroe, K. B., \& Heiman, A. (2008). Memory based store price judgment: The role of knowledge and shopping experience. Journal of Retailing, 84(4), 414423.

Ofir, C., \& Simonson, I. (2007). The effect of stating expectations on customer satisfaction and shop-ping experience. Journal of Marketing Research, 44, 164-174.

Oh, H., Fiore, A. M., \& Jeoung, M. (2007). Measuring experience economy concepts: Tourism appli-cations. Journal of Travel Research, 46(2), 119-132.

Ooi, C. (2005). A theory of tourism experiences: The management of attention. In T. O'Dell \& P. Billing (Eds.), Experiencescapes e Tourism, culture, and economy (pp. 51-68). Koge, Denmark: Copenhagen Business School Press.

O'Sullivan, E. L., \& Spangler, K. J. (1998). Experience marketing: Strategies for new millennium (1st ed.). State College, PA: Venture Publication.

Otto, J., \& Ritchie, J. R. B. (1996). The service experience in tourism. Tourism Management, 17(3), 165-174.

Parasuraman, A., Zeithmal, V. A., \& Berry, L. (1985). A conceptual model of service quality and its implications for future research. Journal of Marketing, 49(4), 41-50.

Patrício, L., Fisk, R. P., Falcão e Cunha, J., \& Constantine, L. (2011). Multilevel service design: From customer value constellation to service experience blueprinting. Journal of Service Research, 14(2), 180-200.

Pine, B. J., \& Gilmore, J. H. (1998). Welcome to the experience economy. Harvard Business Review, 76(4), 97-105.

Pine, B. J., \& Gilmore, J. H. (1999). Experience economy (1st ed., pp. 32-59). Boston, MA: Harvard Business School Press.

Prahalad, C. K., \& Ramaswamy, V. (2004). Co-creation experiences: The next practice in value cre-ation. Journal of Interactive Marketing, 18(3), 5-14.

Pratt, A., \& Aspiunza, A. (2012). Personal experience tourism: A postmodern understanding. In R. Sharpley \& P. Stone (Eds.), Contemporary tourist experience: Concepts and consequences (pp. 11-24). London: Routledge.

Prebensen, N. K., Woo, E., \& Uysal, M. S. (2014). Experience value: Antecedents and consequences. Current Issues in Tourism, 17(10), 910-928.

Price, L. L., Arnould, E. J., \& Deibler, S. L. (1995). Consumers' emotional responses to service encounters. International Journal of Service Industry Management, 6(3), 34-63.

Puccinelli, N. M., Goodstein, R. C., Grewal, D., Price, R., Raghubir, P., \& Stewart, D. (2009). Customer experience management in retailing: Understanding the buying process. Journal of Retailing, 85(1), 15-30.

Quan, S., \& Wang, N. (2004). Towards a structural model of the tourist experience: An illustration from food experiences in tourism. Tourism Management, 25(3), 297-305.

Richards, G. (2011). Creativity and tourism: The state of the art. Annals of Tourism Research, $38(4), 1225-1253$.

Rihova, I., Buhalis, D., Moital, M., \& Beth Gouthro, M. (2013). Social layers of customer-to-customer value co-creation. Journal of Service Management, 24(5), 553-566. 
Rihova, I., Buhalis, D., Moital, M., \& Gouthro, M. B. (2014). Conceptualising customer-to-customer value co-creation in tourism. International Journal of Tourism Research, 17(4), 356-363.

Ritchie, J. R. B., \& Hudson, S. (2009). Understanding and meeting the challenges of consumer/tourist experience research. International Journal of Tourism Research, 11(2), 111-126.

Rodríguez Molina, M. Á., Frías-Jamilena, D. M., \& Castañeda-García, J. A. (2013). The moderating role of past experience in the formation of a tourist destination's image and in tourists' behaviour-al intentions. Current Issues in Tourism, 16(2), 107-127.

Rose, S., Clark, M., Samouel, P., \& Hair, N. (2012). Online customer experience in e-retailing: An empirical model of antecedents and outcomes. Journal of Retailing, 88(2), 308-322.

Rose, S., Hair, N., \& Clark, M. (2010). Online customer experience: A review of the business-toconsumer online purchase context. International Journal of Management Reviews, 13(1), 2439.

Roth, A. V., \& Menor, L. J. (2003). Insights into service operations management: A research agenda. Production and Operations Management, 12(2), 145-164.

Rust, R. T., Zeithaml, V. A., \& Lemon, K. N. (2001). Driving customer equity: How customer lifetime value is reshaping corporate strategy (1st ed.). New York, NY: Free Press.

Ryan, C. (1997). The tourist experience: A new introduction. London: Cassells

Ryan, C. (2000). Tourist experiences, phenomenographic analysis, post-positivism and neural network software. International Journal of Tourism Research, 2(2), 119-131.

San Martin, H., Collado, J., \& Rodriguez del Bosque, I. (2013). An exploration of the effects of past experience and tourist involvement on destination loyalty formation. Current Issues in Tourism, 16(4), 327-342.

Schlosser, A. E. (2006). Learning through virtual product experience: The role of imagery on true versus false memories. Journal of Consumer Research, 33(3), 377-383.

Schmitt, B. H. (1999). Experiential marketing: How to get customers to sense, feel, think, act, relate to your company and brands. New York, NY: The Free Press.

Schmitt, B. H. (2003). Customer experience management. New York, NY: John Wiley \& Sons.

Selstad, L. (2007). The social anthropology of the tourist experience. Exploring the "middle role". Scandinavian Journal of Hospitality and Tourism, 7(1), 19-33.

Sharpley, R., \& Jepson, D. (2011). Rural tourism: A spiritual experience? Annals of Tourism Research, 38(1), 52-71.

Shaw, C., \& Ivens, J. (2002). Building great customer experiences. New York, NY: Palgrave/ Macmillan.

Shugan, S. M., \& Xie, J. (2000). Advance pricing of services and other implications of separating purchase and consumption. Journal of Service Research, 2(3), 227-239.

Small, J., Darcy, S., \& Packer, T. (2012). The embodied tourist experiences of people with vision impairment: Management implications beyond the visual gaze. Tourism Management, 33(4), 941-950.

Smith, A. K., \& Bolton, R. N. (2002). The effect of customers' emotional responses to service failures on their recovery effort evaluations and satisfaction judgments. Journal of the Academy of Marketing Science, 30(1), 5-23.

Smith, S. L. (1994). The tourism product. Annals of Tourism Research, 21(3), 582-595.

Solomon, R. L., \& Corbit, J. D. (1974). An opponent-process theory of motivation: I. Temporal dynamics of affect. Psychological Review, 81(2), 119-145.

Sun, B. (2005). Promotion effect on endogenous consumption. Marketing Science, 24(3), 430-443.

Terblanche, N. S. (2009). Customer experiences, interactions, relationships and corporate reputation: A conceptual approach. Journal of General Management, 35(1), 5-17.

Tung, V. W. S., \& Ritchie, J. R. B. (2011). Exploring the essence of memorable tourism experiences. Annals of Tourism Research, 38(4), 1367-1386.

Uriely, N. (2005). The tourist experience: Conceptual developments. Annals of Tourism Research, 32 (1), 199-216.

Van Doorn, J., \& Verhoef, P. C. (2008). Critical incidents and the impact of satisfaction on customer share. Journal of Marketing, 72(4), 123-142.

Verhoef, P. C., Lemon, K. N., Parasuraman, A., Roggeveen, A., Tsiros, M., Schlesinger, L. A. (2009). Customer experience creation: Determinants, dynamics and management strategies. Journal of Retailing, 85(1), 31-41.

Wakefield, K., \& Baker, J. (1998). Excitement at the Mall: Determinants and effects on shopping response. Journal of Retailing, 74(4), 515-539. 
Walls, A. R., Okumus, F., Wang, Y. R., \& Kwun, D. J. (2011). An epistemological view of consumer experiences. International Journal of Hospitality Management, 30(1), 10-21.

Walters, R. G., \& MacKenzie, S. B. (1988). A structural equations analysis of the impact of price pro-motions on store performance. Journal of Marketing Research, 25(1), 51-63.

Wang, N. (1999). Rethinking authenticity in tourism experience. Annals of Tourism Research, 26(2), 349-370.

Wen, I. (2013). Online shopping of travel products: A study of influence of each dimension of trave-lers' attitudes and the impact of travelers' online shopping experiences on their purchase inten-tions. International Journal of Hospitality \& Tourism Administration, 14(3), 203-232.

Williams, A. (2006). Tourism and hospitality marketing: Fantasy, feeling and fun. International Journal of Contemporary Hospitality Management, 18(6), 482-495.

Wilson, J., \& Richards, G. (2008). Suspending reality: An exploration of enclaves and the backpacker experience. Current Issues in Tourism, 11(2), 187-202.

Winer, R. S. (1986). A reference price model of brand choice for frequently purchased products. Journal of Consumer Research, 13(2), 250-256.

Wong, I. A. (2013). Exploring customer equity and the role of service experience in the casino service encounter. International Journal of Hospitality Management, 32, 91-101.

Woodside, A. G., \& Sims, J. T. (1976). Retail sales transactions and customer purchase pal effects on buying behavior. Journal of Retailing, 52(3), 57-64.

$\mathrm{Wu}, \mathrm{C}$. H. J. (2007). The impact of customer-to-customer interaction and customer homogeneity on customer satisfaction in tourism service - the service encounter prospective. Tourism Management, 28(6), 1518-1528.

Yi, Y., \& Gong, T. (2009). An integrated model of customer social exchange relationship: The mod-erating role of customer experience. The Service Industries Journal, 29(11), 1513-1528.

Yuksel, A., Yuksel, F., \& Bilim, Y. (2010). Destination attachment: Effects on customer satisfaction and cognitive, affective and cognitive loyalty. Tourism Management, 31(2), 274-284.

Zakrisson, I., \& Zillinger, M. (2012). Emotions in motion: Tourist experiences in time and space. Current Issues in Tourism, 15(6), 505-523.

Zeng, M., \& Reinartz, W. (2003). Beyond online search: The road to profitability. California Management Review, 45(2), 107-130.

Zhang, T., Agarwal, R., \& Lucas, Jr, H. C. (2011). The value of IT-enabled retailer learning: person-alized product recommendations and customer store loyalty in electronic markets. MIS Quarterly-Management Information Systems, 35(4), 859-882.

Zomerdijk, L. G., \& Voss, C. A. (2010). Service design for experience-centric services. Journal of Service Research, 13(1), 67-82. 